\title{
JŪRATÉ PAJĖDIENÉ
}

Lietuvių kalbos institutas

Mokslinių tyrimų kryptys: senosios ir dabartinės lietuvių kalbos sintaksė, semantika ir pragmatika, Lietuvos kultūros ir bažnytinių tekstų istorija.

DOI

\section{KRETINGOS TARMĖS ŽODYNE (2011) ATSISKLEIDŽIANTYS ŽEMAITIŠKO EMOCINIO LAUKO KONTŪRAI}

\author{
Outline of the Samogitian Emotional Field as \\ Reflected by Kretinga Dialect Dictionary (2011)
}

\begin{abstract}
ANOTACIJA
Straipsniu tęsiamas kasdieniškame kalbẻjime ryškiausiai pastebimų žemaitiškos tapatybės atspindžių tyrimas. Remiantis Juozo Aleksandravičiaus Kretingos tarmès žodynu (2011) kaip šaltiniu, puikiai perteikiančiu šiaurès žemaičių kretingiškių tarme kalbančių žmonių mentaliteto raišką, šiuo tyrimu siekiama atskleisti žemaičių etnine priklausomybe determinuotų psichinių reiškinių savitumų (plg. Bliumas 1997) sąsajas su žemaitiško kalbėjimo(si) kasdienybėje modeliais. Kasdienybės diskurso atkarpų tyrimas leidžia pamatyti žemaičiams būdingo emocinio elgesio raiškos modelius ir suvokti, kaip tam tikro kalbinio elgesio ypatybės gali paveikti ir formuoti kalbančiųjų emocinį elgesị.
\end{abstract}

ESMINIAI ŽODŽIAI: žemaičiai, tapatybè, autentiškumas, dialogiškumas, emocijos.

\section{ANNOTATION}

The article continues the study on the reflections of the Samogitian identity, which are most prominent in daily communication. Referring to Kretinga Dialect Dictionary (2011) by Juozas Aleksandravičius, which provides an excellent presentation of the expression of mentality of the speakers of the Northern Samogitian Dialect of Kretinga, the present study seeks to reveal the connections between the peculiar characteristics of ethnically determined psychic phenomena of Samogitians (cf. Bliumas 1997) and the models of Samogitian 
daily speaking/communication. The research on the passages from daily discourse enables us to see the models of expression of the emotional conduct inherent in Samogitians and realise how the peculiarities of a certain linguistic conduct may affect and shape the emotional conduct of speakers.

KEYWORDS: Samogitians, identity, authenticity, dialogicity, emotions.

\section{IVADAS}

Straipsniu tęsiamas kasdieniškame kalbejjime ryškiausiai pastebimų žemaitiškos tapatybės atspindžių tyrimas. Juozo Aleksandravičiaus Kretingos tarmès žodynas ${ }^{1}$ (toliau - KTŽ), fiksuojantis šiaurès žemaičių kretingiškių tarme ${ }^{2}$ kalbančiųiu mentaliteto realizacijas kasdienybès situacijose, leidžia pamatyti su etniškumu sietinų psichinių reiškinių savitumų (Bliumas 1997: 40, 48-49) ir žemaitiško kalbejjimo modelių ryšius. Metodinès nuostatos išsamiau aprašytos ankstesniame panašaus pobūdžio reiškinių sąsajas nagrinėjusiame tyrime (žr. Pajèdienė 2018), bet čia svarbu dar kartą paminèti KTŽ užfiksuotos kalbinès medžiagos autentišką dialogiškumą (p. 68-69). Būtent dèl šio išskirtinumo KTŽ iliustracijų visuma, kaip žemaitiško kalbejjimo specifiškumą atskleidžiančių teksto atkarpu sąvadas, yra pajėgi perteikti KALBANČIOJO ${ }^{3}$, atstovaujančio daugybès nuasmenintų individų patirtims ir pateiktims, paveikslą. Rūšiuojant vienokių ar kitokių kasdienybės situacijų išprovokuotus pasakymų modelius išryškejja tam tikro emocinio elgesio savybès, būdingos žemaitiškos kilmès asmenims vien todèl, kad jie mąsto ir kalba žemaitiškai, t. y. tam tikru būdu. KTŽ medžiagos atranką nulèmè semantikos, o kartais ir struktūros, savitumu išsiskiriantys ir (ar) dažniau pasikartojantys tam tikro struktūrinio tipo frazių modeliai, kurie buvo grupuojami pasitelkus minėtame etnopsichologiniame tyrime (Bliumas 1997) išryškėjusius su žemaitiškumu susijusius psichinès veiklos bruožus.

Pirmojoje straipsnio dalyje pristatomas nurodytame etnopsichologiniame tyrime išryškèjusių žemaičiams būdingu psichinių reiškinių savitumas, o antrojoje dalyje dèmesys telkiamas ị tam tikrus emocinès elgsenos modelius, atskleidžiančius ir su etniškumu susijusius pasakymus.

${ }^{1}$ Juozas Aleksandravičius medžiagą šiam žodynui rinko ir kartoteką sudarinėjo nuo XX a. 5-ojo dešimtmečio vidurio iki 2004 metų (plg.: Mikulènienė 2011: XII; Vaišnienė 2011: XX).

2 Tikrasis žemaičių kretingiškių tarmès plotas didesnis nei teritorija, kurios reprezentantų kalbėjimu remiamasi KTŽ (plg.: Aleksandravičius 2011: 5; Lubienė, Pakalniškienè 2015: 76).

${ }^{3}$ Kalbančiojo ir kalbetojo sąvokos straipsnyje vartojamos kaip sinonimai. Vyriškoji giminè pasirinkta kaip apibendrinamoji, galinti atstovauti abiejų lyčių kalbantiesiems, kai iš atkarpos nèra akivaizdi adresanto lytis. 
Straipsnyje žemaitiško kalbẻjimo iliustracijų atkarpos pateikiamos stengiantis kuo tiksliau pakartoti KTŽ taikomą fonetinę transkripciją (apie ją daugiau žr.: Aleksandravičius 2011: 17-18; Vaišnienė 2011: XXIII-XXIX).

\section{SU ŽEMAITIŠKUMU SUSIJUSIŲ PSICHINIŲ REIŠKINIŲ SAVITUMAI}

Prieš porą dešimtmečių atlikto aukštaičių ir žemaičių etnine priklausomybe determinuotų psichinių reiškinių savitumų tyrimo (žr. Bliumas 1997) išvados buvo užfiksuotos kaip išeities taškas išsamiems, ilgalaikiams etninès psichologijos tyrinëjimams (p. 49). Siekiant nustatyti, kuriuos etninei grupei būdingesnius psichinès veiklos ir emocinio elgesio raiškos bruožus galima sieti su gimtosios kalbos poveikiu, pastarąią vertinant ne vien kaip emocinio elgesio modeliu atskleidimo būdą, bet ir kaip pasirinktajai etninei grupei būdingesnių psichinių reiškinių atsiradimo priežastị ir paskatą susidaryti tam tikro elgesio modelius, paranku remtis šio tyrimo metu išryškejjusiais žemaičių ir aukštaičių etniškumu pagrịstais psichinès veiklos bruožais kaip atskaitos koordinatėmis.

Atskaitos tašku pasirinktas etnopsichologinis tyrimas buvo pagrịstas dvinariu subetniniu - aukštaičiu ir žemaičių - skirstymu ${ }^{5}$. Tiriamųjų etniškumas buvo susietas su trimis faktoriais: nuolatiniu asmens gyvenimu subetninei grupei priskiriamoje teritorijoje, subjektyviu savęs priskyrimu žemaičiams arba aukštaičiams ir patarme. Tyrime dalyvavo 120 asmenų: 60 žemaičiu grupès tiriamųjų buvo gimę Sedos miestelyje (Mažeikių r.), pagal patarmę - šiaurẻs žemaičiai; 60 aukštaičių grupès tiriamųjų buvo Balninkų miestelio (Molètų r.) gyventojai, pagal patarmę - rytų aukštaičiai. Abiejų grupių sudètis pagal lytị, amžių ir išsimokslinimą buvo labai panaši. Bendras tiriamųjų amžiaus vidurkis abiejose grupèse buvo maždaug 71 metai (plg. Bliumas 1997: 28-29). Šio etnopsichologinio tyrimo metu sẻslūs tiriamieji aukštaičiai ir žemaičiai buvo apklausti

${ }^{4}$ Atkreiptinas dėmesys, kad tikriniai žodžiai iliustracijose rašomi mažąja raide ir žymimi žvaigždute (apie KTŽ transkripcijos taisymus žr. Vaišnienė 2011: XXIII).

${ }^{5}$ Dvinario (žemaičiai / aukštaičiai) lietuvių kalbos užimamo ploto skirstymo pasirinkimo tyrime argumentus žr. Bliumas 1997: 28. Naujausi tyrimai (žr. Aliūkaitė et. al. 2017) rodo, kad subjektyviai konceptualizuojant tarmes tokia dvinarè tarmių klasifikacija yra viena iš dominuojančių (plg. Pakalniškienė 2018: 261). 
pasitelkiant Hermanno Rorschacho rašalo dèmių metodiką ${ }^{6}$ (bei jos interpretavimui skirtą Johno Exnerio sistemą̧ ) ir Makso Lüscherio spalvų testą ${ }^{8}$. Susisteminus ir apibendrinus tyrimo duomenis (p. 37-40) išryškejjo skirtingas tiriamiesiems būdingos psichinès elgsenos bruožų raiškos intensyvumas. Tai leido skirtingą dviejų grupių tiriamųjų pažinimo procesų, emocinių išgyvenimų ir asmenybès ypatybių bei santykių su daiktine bei socialine aplinka pobūdi susieti su jų etniškumu (plg. Bliumas 40, 48-49). Iš emocinių išgyvenimų raiškos skirtumų paminètina, kad žemaičių imties tiriamųju nerimo išgyvenimai labiau siejosi su šios grupès tiriamiesiems labiau nei aukštaičiams būdingu intravertiškumu. Su asmenybės intraversijos-ekstratensijos linkmėmis buvo susieti ir kai kurie kiti tiriamųjų asmenybès ypatybių skirtumai: „[A]ukštaičiams labiau priskirtina ekstratensiné, žemaičiams - intraversinè asmenybès linkmè. [...] Žemaičiai buvo santūresni, labiau nepriklausomi, uždaresni, pasyvesni ir jautresni. Šios grupès tiriamieji reiškèsi kaip didesni optimistai, jiems buvo būdingas stipresnis Ego“ (p. 49). Rezultatai parodè ir didesnius žemaičių empatijos gebèjimus (p. 42, 49). Nurodytas tyrimas atskleidè intensyvesnę ir sèkmingesnę žemaičių grupès tiriamųjų intelektinę veiklą - ,jie sẻkmingiau naudojo patyrimo abstrahavimo ir integravimo gebejjimus. Senyvo amžiaus žemaičių mąstymas buvo daugiau teorinio pobūdžio. Vaizduotės procesus tiriamieji žemaičiai taip pat naudojo aktyviau" (p. 48-49). Sąveikoje su daiktine ir socialine aplinka žemaičiams „buvo būdingi platesni gyvenimo užmojai, savo elgesi jie linkę planuoti iš anksto. Šių tiriamųjų santykiai su socialine aplinka nebuvo dažni ir įvairūs, o bendravimo ịgūdžiai itin išlavinti““ (p. 49); žemaičiai labiau domėjosi kitais žmonèmis, socialiniai kontaktai jiems atrodè svarbesni, bet žemaičiu grupès tiriamieji išsiskyre intravertiškiems žmonẻms būdingu ryškiu kritiškumu socialinès aplinkos atžvilgiu (p. 42, 49).

Tokie atlikto tyrimo rezultatai subjektyviu požiūriu žemaičiams gali pasirodyti esantys priimtini arba nepriimtini (priklauso nuo asmenybès tipo), būtent todèl jie gali būti ypač naudingi siekiant objektyviau įvertinti žemaitiškų tekstų

${ }^{6}$ Šveicaru psichologo Hermanno Rorschacho rašalo dèmių metodika (The Rorschach Inkblot Method) pirmą kartą aprašyta 1921 m. knygoje Psychodiagnostik (žr. Rorschach 1951), bet ypač didelio populiarumo sulaukė XX amžiaus viduryje. Daugiau žr.: Bliumas 1997: 29-31; Myers 2008: 739-740.

7 Apie J. Exnerio sistemą (The Comprehensive System) žr. Bliumas 1997: 31-32.

8 M. Lüscherio spalvų testo (The Lüscher Color Test) teorija, debiutavusi 1947 m., populiarumo sulaukè kiek vèliau. Apie funkcinę psichologiją ir pagrindines spalvų reikšmes, spalvos ir pojūčio gylio (Depth of Feeling) atitikmenis žr. Lüscher 1971: 27-30, 33-37. Šio testo patikimumą galima ivvertinti subjektyviai, pasitelkus internetinėse svetainėse pateiktas testo versijas (pvz., https://kahome.eu/cgi-bin/lschr.pl?data=45123067; https://onlinetestpad.com/en/test/987-the-luschercolor-test ir pan.). Apie testą dar žr. Bliumas 1997: 32-35. 
sąvadų teikiamą medžiagą. Empirinių duomenų integravimas ị daugiasluoksnę žinojimo lygmenų reprezentavimo visumą padeda juos teisingiau interpretuoti (plg. Coulson 2001: 33). Pasirinkus aptartame etnopsichologiniame tyrime išryškejusias, su žemaitiškumu sietinas emocinès, intelektinès ir socialinès veiklos ypatybes kaip tam tikras KTŽ teikiamos žemaitiško kalbejjimo medžiagos atrankos ir analizės dominantes galima pamatyti žemaičiams būdingų psichinių išgyvenimų sąsajas su tam tikros semantikos (o kartais net ir struktūros) kalbèjimo modeliais. Šiame straipsnyje bus aptariama, kaip KTŽ kalbančiojo pasisakymuose atsiskleidžia žemaičiams būdingesniu psichikos reiškinių pirmosios grupès - emocinių išgyvenimų - realizacijos ${ }^{9}$, pristatant nurodytų emocinio elgesio reprezentavimo žemaitiškame kalbejjime atvejų semantinị savitumą, o esant dèsningiems pasikartojimams aptariant ir emocinès reprezentacijos funkciją atliekančiu frazių struktūrines ypatybes. Laikantis nuostatos, kad patirtis iš kartos i kartą perduodama remiantis išmokimu stebint bei perimamu (plg. Gage, Berliner 1994: 205tt), ir nustačius ryškiausiai emocijas perteikiančias kalbejjimo frazes galima tokius emocinio lauko raiškos kalboje modelius susieti su žemaitiškos tapatybès raiška. Tokiu psichines veiklas dažniausiai perteikiančiu kalbinių modelių raiškos analizè leidžia nustatyti savitesnio žemaitiško elgesio priežastis.

\section{EMOCINĖS RAIŠKOS ATSPINDŽIAI KTŽ KALBANČIOJO PASISAKYMUOSE}

Atsižvelgiant ị tai, kad bet kuris lingvistinès reikšmės aspektas turi būti aiškinamas ir identifikuojamas remiantis asmenų gebejjimais (plg. Weigand 2010: 58), anksčiau aptarto etniškumu determinuotų psichinių reiškinių savitumų tyrimo metu išryškejję kai kurie žemaičiams būdingesni elgesio bruožai leidžia juos pasitelkti kaip dèmesio sutelkimo dominantes skaitant Juozo Aleksandravičiaus Kretingos tarmés žodyną. Šis šiaurès žemaičių kretingiškių autentiško kalbejjimo atkarpas gausiai ir įvairiais aspektais reprezentuojantis sąvadas yra labai parankus šaltinis norint susieti minèto etnopsichologinio tyrimo metu išryškejjusius žemaičių (kurie taip pat buvo šiaurès žemaičiai kretingiškiai) imties tiriamųju grupei labiau būdingo elgesio bruožus su kasdienišku kalbejjimu ir nustatyti, kaip gimtoji kalba gali ne tik atspindèti, bet ir paveikti bei formuoti kalbančiojo mąstymo būdą, emocinius išggvenimus ir asmenybès ypatybes.

${ }^{9}$ Kaip žemaičių intelektinè veikla ir vertybių sistema atsiskleidžia KTŽ kalbančiojo pasisakymuose, dèl šio žodyno teikiamos medžiagos gausumo bus aptarta kitose publikacijose. 
KTŽ kalbančiojo emocinị lauką ir elgesį ryškiausiai reprezentuojančios (t. y. dažniausiai pasikartojančios ir (ar) savitesnès struktūros) kalbejjimo atkarpos bus aptariamos pagal nurodytame tyrime išryškejjusias žemaitiškos grupės tiriamųju asmenybės bruožų dimensijas, vertinant būdingiausių emocinės raiškos aspektų pasireiškimą kasdieniškame žemaičiu kalbèjime.

\subsection{Stiprus ego}

KTŽ kalbantysis savojo ego stiprumą parodo neleisdamas pažeisti asmens tapatumo raiškai bei savigarbai svarbiausių - vardo, asmeninio lauko ir / ar gyvenamosios erdvès saugumo (ir deramo įvertinimo) - parametrų ${ }^{10}$. Stiprų ego turintis KTŽ kalbantysis kitam asmeniui neleidžia savęs įvardyti netinkamu būdu. Tokia nuostata gali būti apginama tiesiogiai - paliepimu ar tyčiojimosi ir erzinimo išprovokuotu fiziniu atoveiksmiu arba preliminariai - klausimu arba pastaba perspejjant kitą asmeni apie nepriimtino įvardijimo būdo įveikimo galimybes. Šias nuostatas pažeidžiantis asmuo gali sulaukti draudimų, moralizuojančių klausimų, pagąsdinimo ar fizinio atoveiksmio (atkreiptinas dėmesys ị 4 sakinic, parodantị, kad pasirinktoji asmens tapatumo parametrų / atributu apgynimo taktika buvo sẻkminga, nes aptariamasis subjektas šaipėsi tik iki laiko ribos sakiniu nurodyto veiksmo atlikimo), plg.:

73) tọ_napràman̂ûok ${ }^{11}$ mọnẹs vẹsúokês várdãs // 227

74) vọ_kãp ẹšruoditọ tâu / ka_tàvì pràman̂uotọ // 227

75) jộukis / jộukis / ẹrệsdigs pộukis // 326

76) ọns mọni vệsãp pràman̂uojẹ / pàkộl sọ_šaukštọ i_kákta nagáva // 227

KTŽ kalbantysis taip pat akylai saugo savo asmeninị lauką ir gina savo gyvenamosios erdvès tinkamumą, neretai pabrèždamas ir paties pašnekovo nurodomų trūkumų nepagrịstumą, plg.:

77) narúŝsuok ${ }^{12}$ mọnẹs // 353

78) naplộrzavûok ${ }^{13}$ mọ́na trúobũos / tọ ệtúok̂ũos nátọi // 310

Stiprų ego parodo ir kalbančiojo prisipažinimai, atskleidžiantys tokius pomègius ir elgsenos būdus, kurie tradicinèje kalbančiojo bendruomenejje néra kotiruojami teigiamai, plg.: deramo standarto neatitinkantị kalbančiojo požiūrị ị ankstyvą dienos pradžią, betikslị bastymąsi ar keliavimo faktiškumą

${ }_{10}$ Apie KTŽ kalbančiojo pašnekovui pateikiamą savęs vaizdą dar žr. Pajèdienè 2018: $73-78$.

${ }^{11}$ prãmanioti - 'pravardžiuoti, vadinti kitaip' KTŽ 227

12 rúšioti, ioja, ioja (sl.) - 'liesti' KTŽ 353

13 pliur̃zavoti, oja, oje (hibr.) - 'niekinti, peikti, koneveikti' KTŽ 310 
deklaruojančius teiginius (atkreiptinas dėmesys, kad juose neigiamos konotacijos tarinių parinktys derinamos su šiais veiksmažodžiais apibūdinamų veiksmų ar patyrimų intensyvumo laipsnio ar hiperbolizuotų parametrų parinktimis):

79) tûoks ộnkstệi kielẹmûos mộn nà_pri_šẹrdẹ̃i // 154

80) mộn dẹdlê tink dīglenietẹ ${ }^{14} / / 76$

81) aš_èsọ̀ apsẹdãužẹ ${ }^{15}$ pọ_vẹ́sa svieta // 71

82) àš èsọ išmaur̂uojẹs ${ }^{16}$ vẹ́sa svieta // 230

Aišku, ryškiausiai KTŽ kalbančiojo ego stiprumas rodomas demonstruojant pasitikejimą savimi ir didžiavimąsi savo pajègumu. Tam dažniausiai pasirenkamos išskirtinai teigiamą savęs vertinimą 'man tai yra lengva padaryti' perteikiančios ir paryškinančios konstrukcijos, realizuojamos kontrastyvines galimybes turinčioje reikšmių amplitudejje nuo kàs mộn (mûms) tàs î́r / tier 'ką man tai reiškia' iki tàs mộn nieka nĩer 'tai man nieko nereiškia'. Pasitikèjimą paskatina ir sustiprina turimų ịgūdžių bei patirties suvokimas (žr. 11 sakinį), kuris projektuojant naują veiklą dažnai įvardijamas atliktinio laiko konstrukcijų parinktimis (žr. 12 sakinị) bei pabrěžiant ankstesnès patirties buvimą ir jos pritaikymo būsimajai veiklai galimybes, plg.:

83) tộ kộpẹta mâlku par_dẹina sọriešêm ${ }^{17}$ / kas_tas_tier mûms // 341

84) àš èsọ̀ na_tûok̂us sọkapûojẹs / kliebệnùs ${ }^{18}$ / drũkt̂âuŝs / vọ̣tùs / lệngvâ // 168

85) kàs_tàs mộn îr / tûoks gr̂́ovọ̀ks tìk nusẹspjâutẹ // 117

86) lig_pệitu e _sọkrộmpûoṣọ ${ }^{19}$ tọ krũva / tàs mộn nieka nier // 183

Kalbètojo ego atskleidžiamas ir vertinant kituc asmenų elgesi ar veiklas; tas vertinimas gali būti pateikiamas dvejopai - rodant narcisistinị savo pranašumą arba stengiantis pabrèžti didesnius kitu gebèjimus, plg.:

87) túok̂ũos dệrbsẹnas ${ }^{20}$ kãp ànệi ka_dệrb / àš napripažistọ // 77

88) pàvīdesĩs jêm ì_kẹtùs véizộnt / ka_têp gràžẽ mûok šûoktẹ // 288

89) vojéi túokì muokiesena kalbietẹ! // 241

Kalbančiojo ego stiprumą parodo ir savojo išmanymo akcentavimas, ir nepritarimas pašnekovo nuomonei. Tam paprastai pasitelkiami žymėto modalumo

\footnotetext{
${ }^{14}$ dyglinéti, $\sim \grave{j e j} a, \sim \overline{e ́ j e}$ - 'vaikštinèti, slankinèti, landinèti' KTŽ 76

15 apsidaužýti, apsidaũžo, apsidaũžé - 'išsibastyti' KTŽ 71

16 išmaurióti, $i$ iója, iójè - 'išvaikščioti (ppr. ko nors ieškant)' KTŽ 230

17 suréžti, $\sim a, \sim \dot{e}-$ 'supjauti, sukirsti' KTŽ 341

18 klèbinis, $\sim \dot{e}-1$. 'glèbio storumo' KTŽ 168

${ }^{19}$ sukram̃poti - 'negražiai, su iškartomis sukapoti' KTŽ 183

20 dìrbsena - 'dirbimas, dirbimo būdas' KTŽ 77
} 
predikatai, pavyzdžiui, imperatyvų su neiginiu pateiktys ar tariamąja nuosaka išreikštų, sąlyginių (nes neįvykdomų) ketinimų deklaravimas, plg.:

90) napizzavûok ${ }^{21}$ mọnẹs / aš_pàts vẹ̀skû žẹnâu // 301

91) nasakik / ộns í bjáurọ̀s / tùjãu kerštâu // 157

92) ka_mọ́na kûojẹs nàbûto prikâltas / diêtûo tâu ì_dọtìs // 74

Kalbančiojo ego išryškina ir prisipažinimai apie emocijų ir savijautos pokyčius, patekus ị kritines ar tam tikru išskirtinumu ar atmetimu pasižyminčias situacijas, plg.:

93) tûoks pàjieme ípîkis / ka_pagátava bovâu dộutẹ anâm sọ_šâukštọ i_kákta // 126

94) ni_skãudi najọtâu ẹš_tã báimê // 127

95) e.pakâušis pranẹ́ža ẹš_tã báimê // 271

96) bộva sộ́jẹ tìk rínktẹnẽ / mộnẹs tện ẹnarẽkîejẹ // 344

\subsection{Optimistinis požiūris}

Optimistinį nusiteikimą atskleidžia KTŽ kalbančiojo pasisakymų atkarpos, pabréžiančios momentinių akimirkų džiugesị ir pasitenkinimą paprastais kasdienès aplinkos teikiamais ịspūdžiais, kuriais dalijamasi su pašnekovu, plg.:

97) mộn vẹ́skas čè mîlọ // 238

98) pasẹsíedau on_krî̀esla e _sî̀edo kãp pũons // 185

99) kãp gràžẽ snệigs čệrš̌k pọ_kúojiems / ka_êtì // 65

100) kãp gràžẽ nârsta pĩlẹs // 252

101) veizî̀ek / kãp gràžẽ káte mộrksa prisẹmêrkọsi // 245

102) veizîiek / kãp gràžẽ sâu vẹ́štas pọệna ${ }^{22}$ pọ_dãrža // 327

103) kûoks gràzọòs pàdârs ta_kanârka // 267

KTŽ kalbančiojo optimistinị nusiteikimą rodo ir dažnas tiesioginio ar perkeltinio alkanumo įvairiems pojūčiams, tarp jų ir norui gražiai atrodyti, akcentavimas, plg.:

104) mệršto mệrštọ kãp nûor̂o válgitẹ // 240

105) pašielọê $\hat{e}^{23}$ nûorọ válgite // 285

106) vọ̀i kãp nûorọ gríbininẹ! // 116

107) kãp nûorọ rûgộsu vagộrklu / sâlstọ / sâlstộ24 // 355

\footnotetext{
${ }^{21}$ pyzavóti, حója, $\overline{\sim o ́ j e}$ (hibr.) - 'koneveikti, niekinti' KTŽ 301

22 purìnti, ìna, ìno - 'purenti, kapstyti' KTŽ 327

${ }^{23}$ pašẽ lęs, usi - 'nepasakomas, didžiulis' KTŽ 285

${ }^{24}$ sálti, sta, sãlo - 'labai norèti, geisti' KTŽ 355
} 
108) lèmẹnàds mộn bộvẹs pabûk / ẹmệrdâms àš ànũo nuorîesọ // 211

109) nusẹnérdînṣ̂o gráži nêrtẹni e_pasẹstràjî̀̂̀ // 254

KTŽ kalbančiojo ir jo artimos aplinkos (vartojamos ịvardžių aš ir mes parinktys ${ }^{25}$ ) optimizmą rodo ir tam tikrų su linksmybėmis susijusių veiklų intensyvumo ir svarbos deklaravimas, plg.:

110) mûms pẹnningã ni_pọ_kâm / bĩ mès línksmã gīvènâm // 256; 297

111) àš ont_tuo šúokệma bovâu patrákọssi ('linkusi') // 58

Optimizmas pastebimas ir KTŽ kalbètojo teiginiuose, išduodančiuose tikèjimą, kad įvykiai klostysis geresne linkme. Tokị požiūrị atskleidžia įvairūs, pavyzdžiui, techninių smulkmenų įsigijimo teikiamos naudos ar kai kurių kritinèse situacijose atliktų veiksmų, apibūdinimai, plg.:

112) dż̃ãugiemûos / ka_ọntéjẹ cẹlẹndrẹnnẹs lệmpas / daug_švệisiãu gĩvêntẹ // 60

113) kníngas par_kára bọvûom ọ̌kásẹ i_žéme // 178

Kalbančiojo optimizmas pašnekovui gali būti perduodamas pasirenkant dvejopą taktiką: pozityvią arba negatyvesnę. Pasirinkus pirmąią pašnekovas apibūdinamas kaip pajėgus įveikti susidariusią kliūti ar nemalonią situaciją, o jo pasitikejjimas stiprinamas tiesioginiais nurodymais ir padrąsinimais, skatinančiais pašnekovą pasikeisti, plg.:

114) kúo_čè baukštẹnis / jog _tâu nĩeks naatsẹttẹks // 41

115) kúo_tọ núrâ kāp_noọ́ris / bûk káp_vẹẹẹ / lĩnksmọs // 259

116) nasọoosi26 / prigọsi27 / vọ_ka_prigọsi / kãp skộstẹ skọ́si // 121

117) ẽk drộsê e.praẽsi // 79

118) mâuk ${ }^{28}$ tẹiŝâu / nieka naveiziek // 230

119) nabûk apk̂̃atẹs ${ }^{29} / / 159$

Pasirinkęs antrąią - „šalto dušo“ - taktiką kalbantysis siekia parodyti, kad pašnekovo pasyvumas, nusivylimas ar ūpo nebuvimas yra akivaizdūs, ir pasiteirauti, ar tokiam nusiteikimui esama rimtesnių priežasčių (o gal ir / arba taip perspèti apie galimus būsimus padarinius). Todèl pašnekovą stengiamasi „pažadinti“ tiesmukišku klausimu (žr. 48-51 sakinius) arba neigiant atsiradusios kliūties ar susidariusios situacijos rimtumą ir jų išskirtinumą (žr. 52-54 sakinius), arba tiesiog formuluojant imperatyvus, plg.:

120) a_tọsérgì / kàs îr / ka_tûoks papiežẹs ${ }^{30}$ ? // 294

\footnotetext{
${ }^{25}$ Apie KTŽ kalbėtojo strategijas ir jų reikšmes daugiau žr. Pajẻdienė 2018.

${ }^{26}$ siùsti, siuñta, siùto - 'niršti ịtūžus, labai pykti' KTŽ 362

${ }^{27}$ prigùsti, priguñda, prigùdo - 'priprasti' KTŽ 121

${ }^{28}$ máuti, na, móve - 2. ‘skubiai eiti, važiuoti’ KTŽ 230

29 apkiaũsti - 'apsileisti, nevykusiam, netikusiam pasidaryti' KTŽ 159

${ }^{30}$ papẽ ětti - 'sumenkti, pasilpti, pablykšti' KTŽ 294
} 
121) a_sérgì / ka_tẽp èsì sộợžẹs $s^{31}$ ? // 346

122) bẹn_apk̂kautâ / ka_nieka nabnûori? // 159

123) a_vêls ẹ_apsieda tàvì ka_têp apdrínkâa $32 / / 480$

124) kàs_čè îr / par_tûoki gr̂ọoọ́ka napáršûoksi // 117

125) diel_nieku nàrẽk kr̂̃ũokte // 72

126) nabûk kñâuka / diel_kũožna šúdnîeki tik_zizì ẹ_zizìi // 177

127) naẹšsẹmẹslîk nieku! // 240

KTŽ kalbančiojo pasakymuose sunkumus linkstama vertinti kaip laikinas būsenas, kurios praeina, pvz.:

128) tộukârt vệsùs mọmìs gộira $a^{33}$ bộva apiemọsi // 119

Su tik tam tikrą laiką trunkančiais gyvenimo apribojimais siejamas vaikų auginimas ir būsto statybos, plg.:

129) ka_vákã pràkọ̀s ${ }^{34}$ / ẹmộn bûs g̀èrãu // 199

130) ka_vákã pâugs / ẹ_mès bẹš̌ki prakvàšêm ${ }^{35} / / 201$

131) par_pûora trêta métu ę_bệngsêm tas_statîbas // 314

Viltimi pagrịstas kalbančiojo optimizmas ryškus ir konkrečias situacijas apibūdinančiuose, ir apibendrintą tam tikrų nepalankių gyvenimo situacijų sankaupos vertinimą pateikiančiuose pasakymuose, plg.:

132) apsẹmàzîns tùjãu žmúoñu / ẹšlẹps // 231

133) àš tòrò tûokẹ nuodiejẹe / ka_vẹskas ệsẽs i géra // 259

\subsection{Didelis atkaklumas siekiant tikslo}

KTŽ kalbančiojo atkaklumas matomas kaip asmens pastangos įveikti jam iškylančius psichinio ar fizinio lygmens sunkumus. Didesnių valios pastangu reikalaujantys veiksmai apibūdinami stengiantis išryškinti įdètų pastangų ir pasiekto rezultato santykị, todèl tam dažniausiai pasitelkiami sudètiniai nuolaidos sakiniai su ka ẹ 'kad ir', o atkaklumu pasiektam rezultatui įvardyti ir įdètu pastangų kiekiui pabrèžti pasitelkiami prieveiksmiai vis tiek, mažne 'beveik' arba pabrèžiamosios dalelytės funkciją atliekantis ir bei tarinių ar jų funkciją galinčiu

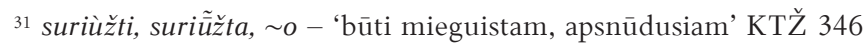

32 apdrìnkti, $\sim$ sta, $\sim O$ - 'pasidaryti neaktyviam, tingiam, aptingti' KTŽ 81

${ }^{33}$ gùira - 'suglebimas, bejègiškumas' KTŽ 119

${ }^{34}$ prakùsti, prakuñta, prakùto - 'suaugti, tapti savarankiškiems (apie vaikus), sustiprèti' KTŽ 199

35 prakvàšti, prakvãšta, prakvã̃so - 2. 'praturtèti, prakusti' KTŽ 201

36 nodiejà (sl.) - 'viltis' KTŽ 259
} 
atlikti ištiktukų pakartojimai, arba tinkamų ir netinkamų ịtikinejjimo būdų nuorodos, plg.:

134) ka_ẹ_klimbọ́udâms ${ }^{37}$ / vẹstệik atējâu // 171

135) mážni nusprúogâu tū_mãiša bàtẹmpdamà // 231-232

136) vẹstệik apsẹzanạ̀jẹ / napadiejẹ ni_gínuojệms ${ }^{38}$ // 107

137) kūkáva kūkáva ẹr_ikūkáva lẹga 193

138) pašlùmšt pašlùmšt ẹr atšlumbáva // 285

139) kộl ${ }^{39}$ e_kộl gâlva vãks / ka_vestûuo i_muokĩkla // 194

140) rộgũ pjâute vadẹna e gerộuọ / e prastộujọ 40 // 317

KTŽ kalbėtojas siekdamas savo tikslų pasirenka įvairias kalbejimo ir elgesio strategijas. Viena iš dažniausiai KTŽ užfiksuotų yra kolektyviniam mes skirtas raginimas, atspindintis būtinybę susitelkti ūkio darbuose reikiamai užduočiai atlikti iki galo ir vienu ypu, su maksimaliu intensyvumu ir pastangomis, plg.:

141) nọjâus pabệnkêm / ębûs pàbẹngtà // 262

142) bẹnbẹ̃nkêm tọ_dệrva / bûs atlẹktûojẹ // 215

143) vệinọ pràdiemọ ${ }^{41}$ vẹskû pabẹnkêm // 316

144) pjáunâm / vírâ / ka_pabẹngtọmêm // 301

145) dàbãr vẹ̀sẹ dẹrrbkêm kẹik gàlêm / vọ_nedielẹs dẹina ${ }^{42}$ pasẹệlsiesêm // 254

Valingo asmeninio elgesio parinkti linkstama sieti su būtinybe, o privalèjimo raiškai mėgstama pasirinkti deontinị veiksmažodị turèti, plg.:

146) mẹ́rtẹna àš tộrọ šẹndẹina bẹngte tū_dârba // 240

KTŽ kalbančiojo atkaklumas pastebimas ne vien dirbant, bet ir siekiant ką nors gauti (dažniausiai tai susiję su kokiomis nors biurokratinėmis pinklèmis ir būtinybe gauti leidimą). Toki požiūrị kalbantysis dažniausiai parodo savo pašnekovui skirtuose patarimuose (žr. 75-76 sakinius) arba dalydamasis asmenine patirtimi (žr. 77-79 sakinius), ketinimais, kurie gali būti išsakomi atvirai ir /ar pasirinkus neapibrèžtos referencijos įvardị $t u^{43}$ (žr. 80-81 sakinius), plg.:

147) prašîk grażộujọ ẹdộus // 114

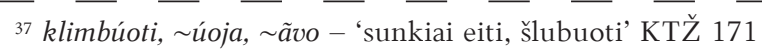

${ }^{38}$ gýniojimas - 'neleidimas, draudimas, atkalbinèjimas' KTŽ 107

39 kùlti (iškùlti, prikùlti) gálvą - 'galvą sukti, kvaršinti’ KTŽ 194

${ }^{40}$ prastúoju - 'piktai, piktuoju' KTŽ 317

${ }^{41}$ tuõ (víenu) prãdemu - 'be perstojimo' KTŽ 316

42 Čia junginys nedèlès diena - 'sekmadienis'. Apie slavizmo nedèlès reikšmes junginiuose žr. Babickienè 2005: 12 .

${ }^{43}$ Apie neapibrèžtos reikšmès referenciją (plg. Haspelmath 2000: 11), kuri lietuvių kalbotyroje apibūdinama kaip tu vartojimas apibendrinta (plg. Valeckienė 1965: 668) ar neutralizuota tu reikšme (plg. Rosinas 1996: 26) ar kaip gramatinès metaforos atvejis (plg. Judžentis 2012: 114); apie neapibrèžtos referencijos tu žemaitiškame kalbejjime žr. Pajèdienè 2018: 86-87.
} 
148) papiràgînk ${ }^{44}$ tọ ànộu / vọ_kẹtêpp nagâusi nĩeka // 299

149) páprẹka ${ }^{45}$ dàvî̀m màtẹninkộu ẹ gàvûom gerésne žéme // 277

150) nulédệs $s^{46}$ kèès nedielẹs apệnt nuejjâu pri_pẹrmẹninka // 210

151) vẹ̀suok̂̃u pînkli ${ }^{47}$ tọíejâu / pàkộl atgavâu sáva pẹnîngus // 298

152) jê nàsọtệks / rẽks paklèperộutẹ $e^{48} / /$ ka_paklèperộuji / e gâuni / vọjê nê / nieka // 170

153) dešimtẹnẹ davê / e._praẽsi // 73

KTŽ kalbančiojo atkaklumas matomas ir ginčo situacijose, kurios gali būti sprendžiamos nurodant, ką pašnekovas privalo daryti (žr. 82 sakinị), arba siekiant savąị teisumą vienaip ar kitaip įrodyti (žr. 83-85 sakinius), plg.:

154) tâu prìgộl ${ }^{49}$ muokietẹ dọ̀ sikộ dáugãa // 119

155) nọ lažínkevûos / matîsi / ka_mọ́na tệisà // 208

156) líkevûos ${ }^{50}$ / matisi / ka_mọ́na tệisà // 215

157) rẽks mộn tū_lãikrašti pakavúotệis ${ }^{51}$ ękệšte brẹgadĩerộu ì_akis // 152

Savo atkaklumą KTŽ kalbantysis pabrèžia ir pasakodamas apie ịgytą patirti bei nuveiktus darbus, ir siekdamas tinkamo įvertinimo kalbamuoju momentu. Tam mėgstama pasitelkti pastangų kiekio ir spartumo nuorodas (plg. 86-87 sakinius) ar išryškinti nusiteikimą viską atlikti vienu kartu (plg. tokio tipo kaip geriau padarai / atlieki iš karto ir viskas konstrukcijas 88-89 sakiniuose) ir gauti už atliktą darbą atlygị (žr. 90 sakinị), plg.:

158) rēkiejẹ papràkaitộute / pàkộl prasẹgīvenûom // 316

159) priš_vákara ka_plọstíejiem ${ }^{52}$ / ka_plostiejiem / noriejiem bẹngtẹ // 312

160) nàrẽk lúodintệis ${ }^{33}$ / gèrãa padarâ ẹškãarta / e _bẹ̃ngts krộkis // 220

161) àš êsọo tâu lúodintệis / gèrãu àtlệikti vẹ̀skû / ẹ_vẹskas // 220

162) vện tìk ọ̌_ã̃ộu aš_tâu nadệrbsọo // 22

KTŽ kalbėtojo diskursas rodo, kad atkaklumas gali būti siejamas ir su drąsa, kuri teigiamai konotuojamose situacijose paprastai įvardijama pasitelkus skolini

\footnotetext{
${ }^{44}$ papirãginti / papirãgyti (hibr.) - 'papirkti, pasigerinti' KTŽ 299

${ }^{45}$ pãprikas - 'kyšis, papirkimas' KTŽ 277

${ }^{46}$ nuléisti - 2. 'praleisti laiko tarpą' KTŽ 210

47 pìnklès - 2. 'kliūtys' KTŽ 298

${ }^{48}$ paklẽperuoti (hibr.) - 'pasigerinti, dovaną, kyšį duoti' KTŽ 170

${ }^{49}$ priguléti, prìgulia / prìgula, $\tilde{e} j \dot{j}$ - 'priklausyti, tekti' KTŽ 119

50 lýgti, $\sim$ sta, o - 2. 'eiti lažybų' KTŽ 215

${ }^{51}$ pakavóti (hibr.) - 'paslèpti’ KTŽ 152; pateiktame pavyzdyje sangrąžinis pakavoties vartojamas reikšme 'pasilaikyti kaip įrodymą'.

${ }^{5}$ plustéti, plùsta, éjè - 2. 'smarkiai dirbti' KTŽ 312

${ }^{53}$ lódintis, $\sim$ inasi, $\sim$ inosi - 'leistis, kad kritikuotų, klausinètų, bartų' KTŽ 220
} 
atvõžnus, $-i$, o neigiamai konotuojamose (t. y. nepasidavimą kitų įtakai pabrèžiančiose) situacijose laikoma užsispyrimu, nepaklusimu, neįsiklausymu ị kito nuomonę, nepasidavimu įtikinèjimams (plg. užsispyręs, atbulas / atbulai darantis, nepersakomas), pvz.:

163) tas_mûsa vãks nu_pat_máža bọ́va atvũožnọs // 33

164) jẽb_kọ́r ànũo ẹ_nanuvési / ọzsẹspîiẹs káp_uožĩ // 132

165) ožsẹspîrẹs tas_mûsa vãks / kũosi ${ }^{54}$ nakũosi / vẹstệik nĩeka naẹšgâusi // 202

166) ộns napalêd55 / ẹvệskas / nûors ọžmùšk ànũ // 210

167) tâu nagâl pársakitệ/ tọ sáva ẹsáva // 354

168) napársakîisi/ namẹsslik/ àtbộls káp viežis // 354

Toks su atsparumu kito asmens (ar kitų asmenų) poveikiui siejamas atkaklumas gali būti apibūdinamas ir stengiantis išryškinti (pavyzdžiui, besikartojančių tarinių nuorodomis) tų veikiančiųjų / veikusiųjų asmenų pralaimėjimą arba patarle, kad skiriant laiko ir pastangų viską vienaip ar kitaip galima įveikti, plg.:

169) dráskẹ dráskẹ / pliešẹ pliešẹ / vọ pàskộu e dáve pakájọ // 271

170) drûkts ẹ́škp / ẹlga nuvīn̂io // 82

\subsection{Ryškus internalumas}

Stiprus ego, optimistinis nusiteikimas, pasitikejjimas ir atkaklumas ne tik tarpusavyje susiję, bet ir nulemia ryškų asmens internalumą - suvokimą ir drąsą prisiimti atsakomybę už savo veiksmus. Internalumu pasižymintis asmuo su juo susijusių įvykių priežastimi yra linkęs laikyti savo paties elgesį, charakterị, gabumus, gebėjimus ir vidinę kontrolę. KTŽ kalbėtojo diskurse galima rasti tokios nuostatos realizaciju atviro (kai patirtis ir ịvertinimai adresatui perduodami tiesioginiais nurodymais ar raginimais kaip 99-100 sakiniuose) ar netiesioginio (kai asmeni apibūdinantys vertinimai pateikiami kaip pagiriantis ar supeikiantis pasakojimas kitiems - dažnai apkalbamam subjektui būnant tokių pasakojimų ar apibūdinimų liudininku kaip 101-102 sakiniuose) auklèjimo modelius perteikiančiuose pasakymuose. Juose asmens atsakomybè už poelgius susiejama su tam tikrais asmens raidos tarpsniais, todèl aptariamas subjektas ar tiesioginis adresatas laikomas pasiekusiu reikiamą brandos lygị tik tuomet, kai geba savarankiškai priimti sprendimus ir (ar) realizuoti būtiniausius poreikius, plg.:

171) rî̌žkis / kãp nûori / tẽp e._darîk // 346

\footnotetext{
${ }^{54}$ kvõsti, kvõta, kvõte - 'tardyti, klausinèti' KTŽ 202

${ }^{55}$ nepaléisti - 2. 'savo laikytis' KTŽ 210
} 
172) rî̌zkis / pàts žẹnâ / nabmážọ èsì // 346

173) je jè / jáu dẹdlĩ dẹdlĩs / prũota jau_tộr / ali_šẹ́ktẹ napràšûs // 317

174) lai_rî̌žtas / aš_nanûorọ kệstệis ì_anũo rēkalus // 347

Atsakomybė už savo elgesị padeda asmeniui būti valingam ir siekti užsibrèžtu tikslų. KTŽ kalbantysis tokias nuostatas sieja su charakterio tvirtumu, tai vertindamas kaip įmanomą ar ịvykusį sẻkmingą susitarimą su savimi, plg.:

175) jê žmúogọs ọžsẹkẹ̣itieji氵 / kū_nûors nusẹsstatâ / tà nabgáudâ nì_kuok̂u vieju // 161

176) àš tộukârt ọ̌sệkẹitiejâu ẹ_pasak̂âu / dáuĝ̃ãu ni_láša // 161

\subsection{Nepriklausomumas}

KTŽ kalbančiojo diskurse ryšku, kad asmens nepriklausomumo samprata labiausiai siejama su stipriu ego, pagarba kitam asmeniui ir savigarba. Tokią nepriklausomumo sampratą stengiamasi formuoti vis pabrěžiant būtinybę nepažeisti svetimos asmeninès erdvès (siaurąja ir plačiąja prasme) ribų. Ši nuostata ugdoma įvairiais draudimais, neleidžiančiais liesti nei kito asmens, nei svetimu daiktų, bei kartojimais ir priminimais, kad nedera likti skolingam, plg.:

177) napašûuok mộn pláukũ / ẽk šàlẹn! // 285

178) nìkumèt nakọšink ${ }^{57}$ na_sáva dâkta // 199

179) nakộsînkẹt / vàkã / nieka / kas_na_jûsa // 199

180) rẽk stẹngtệis ẹš_pàstarũojii sk skũola atdọ́utệis // 284

Realus nepriklausomumas KTŽ kalbančiajam pirmiausia siejasi su nuosava gyvenamąja erdve, plg.:

181) ka_tọrì sáva truobálẹ / nàrẽk sọ́ svetẹmãs kèreżuotệis ${ }^{59}$ // 156

182) sáva bọtûo ${ }^{60}$ kũožnọs i pũons // 57

KTŽ kalbantysis pabrèžia, kad nuosavam būstui sukurti yra / buvo dedamos visos pastangos (žr. 111 sakinị), kad nuosavų namų, nesvarbu, kaip jie beatrodytuc ir kaip būtų įvardijami, turẻjimas leidžia pajusti gyvenimo realumą (plg.

\footnotetext{
${ }_{56}$ užsikietéti - 'užsispirti, laikytis savo' KTŽ $\overline{161}$

57 kùšinti, ina, ino - 'liesti, imti' KTŽ 199

58 iš pãstarai (pãstarojo) - 'iš paskutiniųjų, labai stengiantis' KTŽ 284

59 kèrežioties, iojas, iojes - 'pyktis, erzintis' KTŽ 156

${ }^{60}$ bùtas - 'gyvenamasis namas, troba, pirkia' KTŽ 57
} 
frazes ir gyvenu; ir gyvena), suteikia galimybę gerai jaustis ${ }^{61}$ ir didžiuotis savarankiškumu (žr. 115-116 sakinius), plg.:

183) ẹ̌spàstarājê stẹngiemûos pasẹstatitẹ kuokẹnûors truobále // 284

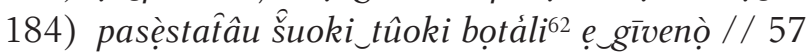

185) nusệkriê̂â šẹtã ẹšmûoli tûokẹ būdále e gívenọ̀ // 186

186) ànà tộr tûokẹ ọrkštọ́lẹ ${ }^{63}$ e gìvên // 465

187) če _ộna nọmã // 262

188) nọmmệi mọnnệi parvẹ̣s ${ }^{64}$ gèrãu // 280

Nuosavų namų kaip nepriklausomumo garanto nuostata ryški ir KTŽ kalbančiojo perspejimuose ar prisipažinimuose apie sunkumus, atsirandančius praradus galimybę gyventi atskirai ir savarankiškai, plg.:

189) nọ_nẽk prì_anũ gīvêntẹ / vọ_kũ ẹšgràjîisi // 113

190) vẹ́sa gĩvènẹ́ma givvenọs ọt_sávẹs / nalẹngvọ kârštẹ prì_vākũ // 147

\subsection{Nerimas}

Nuogąstavimai dèl atitikties vertybinès skalès reikalavimams nerimą ir / ar rūpestị išgyvenantị emocijos patyrẻją grąžina ị praeitị ir prisiminimus (plg. Helm 2009: 23-27), pvz.:

191) sọegraudẹnâu ${ }^{65}$ / ka_tẽp baẹšéjẹ // 114

KTŽ kalbėtojas nerimą linkęs suvokti kaip širdies skausmą sukeliančią emociją, kurios atsiradimą sieja su neatliktomis užduotimis ir artimo asmens elgesiu ar likimu, plg.:

192) vãrgâ rūpèsnê šẹdéle sọpliéšis // 351

193) sọgẹla mộn šệrdẹs66 / ka_tas_vãks nabûtọ kọ_nuklidẹs 107

194) mážos vãks kvartũga dráska / dẹdẹlis šệrdi // 201

195) mộn gêl šệrdẹ̀s díel_anũo // 103

Žemaičiams labai svarbūs kūno kalbos ir veido mimikos siunčiami signalai, todèl kalbètojas kitą asmenį kankinantị nerimą lengvai atpažįsta iš elgesio ir kūno kalbos, plg.:

\footnotetext{
${ }^{61}$ Apie palankų neturtingų, bet nuosavų namų vertinimą lietuviškoje namu koncepto sampratoje plg. Rutkovska 94, 93, 107.

62 butãlis - 'prastas namas' KTŽ 57

${ }^{63}$ urrkštule, ur̃kštynè - 'landynè, mažas, menkas kambarèlis' KTŽ 465

${ }^{64}$ parvìs - 'užvis, labiausiai’ KTŽ 280

${ }^{65}$ susigraudínti - 'susigraužti, susirūpinti’ KTŽ 114

66 širdis sugìlo - 'apèmè nerimas' KTŽ 107
} 
196) ẹnûosẹs nuknẹ́ba ệs_tũo sọsẹrúpẹnẹma // 178

197) ta_mûsa sọiede bàsiedontì gâlva nulédọsî̀ / àš sọpratâu / ka_kas_nûors atsẹtệka // 210

Savo paties nerimastingumą KTŽ kalbėtojas linksta sieti su praeities įvykių keliamais prisiminimais, pvz.:

198) ka_prasẹdiejẹ nàgộndas ${ }^{67}$ / tẽp vẹ́inà pọ̀kẹtã ẹ_éejẹ // 248

Neigiami praeities patyrimai KTŽ kalbančiajam neleidžia būti tikram dẻl savo būklès ir galimybių kalbamuoju metu ar tikèti ateities įvykių sẻkmingumu, plg.:

199) dàbãr èsọ̀ ne_pakârts/ ne_nulêsts // 210

200) pakọl_kàs niekộu nàsêrgọ / bèt gàlọ̀ sọsẹrrgte // 254

201) àš tệkrã atêsọ / nèbệnt kàs_atsẹtệktộm // 254

202) nažẹnâ / kũ rîtuo_dẹinà gâl pagẹidûote // 346

203) sọ_rītuo_rîtọ nažẹnâu kãp bûs // 346

Vis dèlto kartais KTŽ kalbètojas nerimastingumo apimtą asmeni gali apibūdinti ir sarkastiškai (tai gali būti pateikta ir kaip autoironiškas vertinimas), pvz.:

204) éjọsi i_miestáli / atsẹmệnọsi / ka_šiepális naọždarîts // 237

Laikantis sarkastiško požiūrio išeitimi iš nerimastingumą keliančios situacijos gali būti pasiūlomas abejingumas, plg.:

205) gèrâu nusẹspjâuk / vọgráužẹmûos ${ }^{68}$ če_nĩeka nabipadies // 116

\subsection{Jautrumas}

KTŽ kalbančiojo jautrumą įvairiems trikdžiams rodo jo pastabos, ịvardijančios šalia esančio asmens judrumą ir (ar) triukšmą, kaip erzinančius, išblaškančius dėmesi ar neleidžiančius miegoti. Priekaištaujantysis savo jautrumą stengiasi apginti klausimu arba pastaba, kurioje nurodomi erzinančio, trikdančio elgesio apibrèžtumo (pvz.: čia, tas, ta, tas tavo, tas mūsu, su tuo savo / su tais savo, toks, su tokiu ir pan.) ar neapibrèžtumo (plg. bet kokio trikdžio nuorodą 142 sakinyje), veiksmo intensyvumo išryškinimo (pvz., pasitelkus junginius kas per ar kiek gãli), per ilgos trukmès (pvz., visos / kiauros dienos ar nakties) ar nesiliaujančios veiklos parametrai, o neretai įvardijamos ir susierzinimą sukèlusio valingo ar nevalingo elgesio ar veiklos pasekmès, tokios kaip emociju kaita, dèmesio ir / ar atminties sutrikimai ir pan., plg.:

${ }^{67}$ nãgand $\overline{-}$ - 'didelè bèda, nelaimè, vargas, baime, išgąastis' KTŽ $\overline{248}$

${ }^{68}$ griáužimos - 'kankinimasis, gailèjimasis' KTŽ 116 
206) kúo_čè prâusi ${ }^{69}$ prì_ausũ! // 319

207) kúo_tọ́ krọ́nkì70 vẹssa dẹina ba_párstûoji? // 184

208) tas_táva nũognọs kọšiejiems ${ }^{71}$ mọnnì i_zlásti vèd // 199

209) sọ_tọ_sáva lộrlẹnẹmọ ẹ̌šprũota ẹšvési // 219

210) ài / kà_tọ̀ sọ̀_tãs sáva kvaitolèvẹmâs nàbệngi // 200

211) namàtarộuk sọ̀_rọkọ̣ mộn prì_akìs // 229

212) prarẹâu $u^{73}$ sọ_tãs vákãs / kúcčè pàsakuojâu // 346

213) ka_tọ kộšìn / àš nágalọ ơ̌mẹgtẹ // 199

214) bẹsški kàs brệkš / ệaš_givis! // 52

215) vãks kvíekš / àš jáu gî̀s // 201

216) vẹ́sa nákti káurmệigo mẹigúojâu // 159

217) sọ_tûokọ knárklọ gọliedâms naẹšmẹigûosi / ba_nêrvu palệksi // 176

218) tûoks báisọ̀s k̂ãulẹs kvīkệms / ẹr_ãusis bẹjjẹ // 202

219) kàs_pãr parpệms tuo_màtûra / ẹr_ãusis skệd // 279

220) kệik tẹ́i macaklietâ gâl pãrptẹ / ikîriejẹ lig gî̀a kâula // 280

221) nagẹ́rgždink tũ_vartélu / tẽp êt par_gâlva // 108

KTŽ kalbančiojo jautrumas matomas ir jo santykyje su ji supančiais asmenimis - jis pastebi ir aptarinejja kitu jautrumą bei emocingas reakcijas į tiesmukišką savo paties kalbejimą, kurị sieja su būtinybe išsakyti pastabas ar nuomonę, vertinamą kaip tiesa ar teisybè, plg.:

222) kàs_pãr lepnibẹ ànũos / žũodi pasak̂âu / ẹ_apsệkr̂̂okẹ // 212

223) ànà ẹ_ọ̌sẹ́degẹ / ka_pasak̂âu tẹisa // 137

Siekdamas pasitikejjimo KTŽ kalbantysis pabrèžia išsiugdytą savo pastabumą ir gebejjimą atpažinti kito asmens kūno kalbos tikrąsias reikšmes, plg.:

224) bệ_tọ_malộuj / jog_nûosẹs kũmpst? // 196

225) *ž̀ûbak / jau_tọbriežzi ${ }^{75} /$ matâu ẹš_ak̂u // 52

226) ệs_akũ matitệis ka_malộuji / ẹš_mãiša illa vẹ̀sumèt ẹ̌slênd // 227

\footnotetext{
${ }^{69}$ priáusèti, priáusa, èjè - 'kosèti' KTŽ 319

70 krañkti, $\sim a, \sim \dot{e}-2$. 'kosèti' KTŽ 183-184

71 kušéjimas - 'krutejjimas' KTŽ 199

72 liùrlinimas - 'nelabai tikęs griežimas' KTŽ 219

${ }^{73}$ prarýti - 2. 'staiga pamiršti' KTŽ 346

${ }^{74}$ kušéti, kùša, éjje - 1. 'judèti, krutèti' KTŽ 199

75 brëžti, $\sim a, \sim \dot{e}$ (hibr.) - 2. 'meluoti' KTŽ 52
} 


\subsection{Ryškus intravertiškumas ${ }^{76}$}

Savo ar kitų polinki užsisklęsti savyje KTŽ kalbantysis vertina kaip drąsos stoką. KTŽ teikiama diskurso atkarpų medžiaga rodo, kad nedrąsumo, baikštumo, retkarčiais įvardijamo ir baime, ar gėdingumo raišką lemia susidūrimas su nežinomais dalykais - svetima erdve, nepažisstamais žmonėmis ir nežinomais tvarkos modeliais. KTŽ kalbantysis toki elgesį dažniausiai atpažįsta vaikų elgesyje, plg.:

227) mûsa vákã nàdrês prì_svetẹmũ // 81

228) palàbîink tū_vãka / ọns pàts nàdrês // 203

229) ìvèsk tū_vãka / ọns nàdrês ijẽte // 81

230) dẹdlê gíedings tas_vaikélis // 102

KTŽ kalbantieji nuosavą baikštumą ir nedrąsumą įvardija kaip savybę, trukdančią jiems bendrauti su kitais žmonėmis, plg.:

231) nadrộusọ bộva liste ì_akìs // 79

232) àš nadrēsâu ànũo klâustẹ // 81

233) àš nàdrêso vệinà ête // 81

Baikštumo ir susivaržymo įveika KTŽ kalbančiojo yra vertinama kaip sėkmès garantas, plg.:

234) drộsêm žmũogộu vẹ̀sộr sẽnkas // 79

Atsiradus būtinumui spręsti kokias nors problemas ir bendrauti su svetimais žmonėmis, KTŽ kalbantysis stengiasi įveikti savo nedrąsumą vidiniais ịtikinėjimais arba pasikviesdamas į pagalbą kitą asmeni, plg.:

235) apsẹdrộsệnẹs ${ }^{77}$ e._nuējâu prì_anũo skúolũos prašitẹ // 79

236) ka_dvẹjâu nuẽsêu / bûs drộsãu // 87

Mažai bendraujantị, vengiantị kalbètis ir besistengiantị laikytis nuošaliau asmenị KTŽ kalbètojas linkęs apibūdinti neiginių konstrukcijomis - asmuo laikomas nepastebimu ir (ar) neteikiančiu jokios informacijos, nepratariančiu žodžio ir pan., plg.:

237) tuo_vãka kãp jệ ẹınier / dẹdlê tikọ̀s vãks // 139

238) ẹš_tũo vãka nikumèt nieka naẹškũosi / nieka nasọžẹnuosi // 202

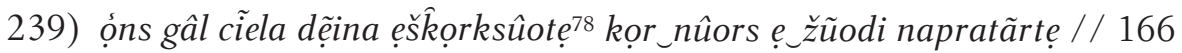

\footnotetext{
${ }^{76}$ Remigijaus Bliumo tyrime remiamasi Hermanno Rorschacho pateiktu intraversijos, kaip proceso, pasižyminčio lanksčiomis asmens galimybẻmis ir polinkiu užsisklęsti savyje atsižvelgiant ị aplinkybes ir aplinkos sąlygas, suvokimu (plg. Bliumas 1997: 42-43).

77 apsidrąsinti - 'pradrịsti, imtis drąsos, ryžtis' KTŽ 79

78 iškiurksóti - 'ištūnoti’ KTŽ 166
} 


\subsection{Uždarumas}

KTŽ kalbančiojo frazės rodo, kad žemaičiams uždarumas labiausiai siejasi su privačios erdvès ir asmens privatumo apsauga. Visoje KTŽ teikiamoje medžiagoje ryškiai pastebimas kalbančiojo polinkis ir (ar) pasirinkimas gyventi atokiai, vengti pašalinių žvilgsnių, į savo erdvę neįsileisti nepageidaujamų žmonių arba bent jau būti tikram dèl savo privatumo kontrolès. Vengiant netikèto ir / ar slapto stebètojo yra pasitelkiamos durys ir užraktai, langinès ir (ar) užuolaidos, susikuriamos kliūtys (pvz., užariamas kelias, gyvenama atokioje vietoje), atrenkami žmonès, kuriems neleidžiama patekti į namus ir pan., plg.:

240) kũ_čè baknĩpûjiji ožsẹdárẹs / ka_nieks naijẽtọ // 178

241) jau_têmst / ọzdarẹniek longenničẹs // 206

242) ožsẹdiesêm pirânkas ${ }^{80}$ / ęnabšveịộus nákti prọlộngus // 299

243) rêk i_šẹkẹninka kũobẹni ${ }^{81}$ idietẹ / ka_galietọ ijéjos ọzsệkabîntẹ // 179

244) tọ_kéli ơzãarsọo / ka_nieks navažộuto // 31

245) mûms dẹdẹlie lẹngvenibẹ / ka_nabvažộu par_kệima vẹ̀suokệi pẹjũokâ // 211

246) gīvènâm túok̂ũo nùšẫũo vệitûo / nieks nì̀umèt e _nàožẽêt // 263

247) tuok̂ũ prisẹsprúogiêlu àš ẹ_i_trûoba nalêdọ // 320

KTŽ kalbančiojo uždarumas atsispindi ir bendravimo manierose: jis nėra linkęs atvirauti, ypač su įkyriais smalsuoliais, o vengimą atvirai kalbètis su kitais pagrindžia atsakomybe už savo paties likimą ir nenoru guostis ar sulaukti gailesčio, plg.:

248) mộn nàtĩnk / ka_dẹdlê ọstúojọệs kamọntẹnie // 142

249) súnkọ̀s mọ́na gīvènệms / àli nĩeks napadies / kọ_pridies ẹ_bĩedavuotệis $/ / 74$

KTŽ esama pasakymų, rodančių, kad norintieji pažeisti uždarumo nuostatas gali būti kontroliuojami, o turintieji polinkị šios nuostatos nesilaikyti apibūdinami neigiamos konotacijos ir (ar) elgesio ryškumą / išskirtinumą apibūdinančiais epitetais, plg.:

250) vákũ nalêdọ êtẹ pọ kẹimùs // 312

251) mûsa vāks tệkrọs patvâiskis / pàrẽt ẹš_muokĩklâ ẹ_ệśtres ${ }^{82}$ // 287

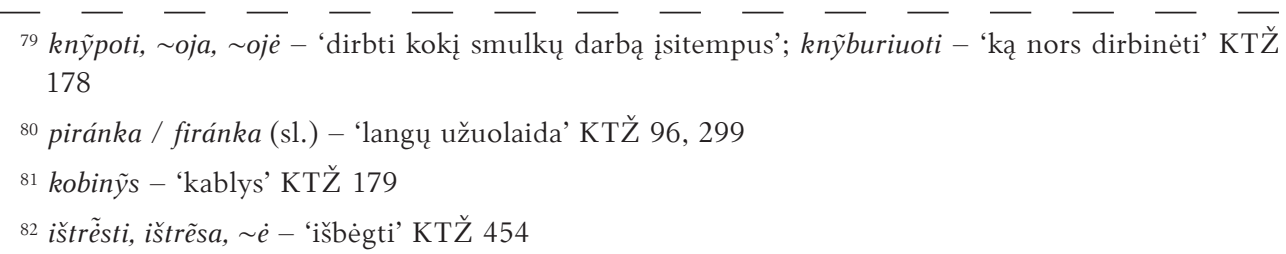


Uždarumą gali lemti ir prasta savijauta. Su ja susijusį nenorą bendrauti KTŽ kalbètojas įvardija kaip atpažizstamą iš kūno kalbos, plg.:

252) pamuosẹkáva sọ̀_rọnkọ ẹ_vĩel sọsệrệitẹ i_kamūlâti // 242

253) àkì panarẹ́na e đnieka nabsákẹ // 251

254) ànà gâlva panarẹnọsî̀ êt // 251

Kartais vengimas bendrauti būna siejamas / susijęs su tam tikromis paslaptimis, pvz.:

255) tas_vãks lèptẹliejẹ vẹ́sa tệisa // 212

256) nikâm napàsakûok kü gẹrdiejẹs // 257

KTŽ esama ir diskurso pateikčių, parodančių, kad uždarumo nuostatos laikymasis gali būti ir priverstinis, o pasitikejjimas ir noras išsipasakoti dažniausiai atsiranda bendraujant ir būnant kartu, plg.:

257) nábtộọo pinâusu ${ }^{83}$ / diel_tũo ę_ệntọ nọmệi // 297

258) ka_ẹšgeri / atsẹrộnd ẹ_plèpesiis ${ }^{84} / / 304$

259) mès basiediedamis i_plépesi ijèjiem // 304

\subsection{Pasyvumas}

KTŽ gausu frazių, kuriomis kalbantysis skatina kitų arba paaiškina savąii pasyvumą, susitaikymą ir nuolankumą. Nuolankumo iš pašnekovo gali būti reikalaujama ar pageidaujama tiesioginiais nurodymais, paaiškinimais ir patarimais, plg.:

260) nagínčîis / jê gèrâ nažẹnâ // 107

261) kúokì tâu biedà / ọn gâlvọ mẹita nieks natáša // 24

262) nabûk pár_saldọs / nurî̀s / nabûk pár_kartọ̀s / ẹsspjâus // 345

KTŽ kalbètojas faktinę savo ar kitų būklę ir nepasitenkinimą stengiasi priimti nuolankiai, pabrěždamas likimo lemti arba bandydamas pasyvumą (ar tingumą) susieti su santūriais savo norais ir filosofišku požiūriu, plg.:

263) nọ nieka napašệksi85 žmúogọs / tẽp jáu bộva žadieta ${ }^{86}$ // 495

264) rẽk bûte kộntẹnâm ${ }^{87}$ sáva lẹkẹmọ // 144

265) mộn nì_kuok̂u ệstâigu nàrẽk / kãp_ĩ / tẽp e gèrãa // 129

\footnotetext{
${ }_{83}$ pináusai $\overline{(\mathrm{sv} .)}$ - 'finansai, pinigai' KTŽ 297

${ }^{84}$ plepesỹs - 'šnekučiavimasis, pašnekesys' KTŽ 304

${ }^{85}$ negalèti pašikti - 'negalèti padaryti', plg. KTŽ 495

${ }^{86}$ žadéti, žãda, éjé - 2. 'skirti, lemti' KTŽ 495

87 kañtenas, $\sim a$ (sl.) - 'patenkintas' KTŽ 144
} 
KTŽ kalbančiojo požiūris ị ginčą dažnai parodo ir tikrąsias žemaitiško pasyvumo priežastis, kuriomis gali būti nenoras aiškintis su už save impulsyvesniu, labiau užsispyrusiu asmeniu ar paklusimas svetimai nuomonei, plg.:

266) bẹâu bártệis sọ̀_anộu / ka_nagáut̂̂o piérũos 88 // 292

267) bejûok ànũ ẹ_ožkàbavûotẹ 89 // 137

268) údîk naúdẹjẹs / kãpi_sệina // 463

269) tûoks jau_ì ànũo karàktûorọ / nĩeka nabipadarîisi // 146

270) ọns mònệi paplekšnûojẹ par_péti ẹlệipe nusẹlêstẹ // 304

KTŽ iliustracinė medžiaga rodo, kad pasyvūs ir nuolankūs asmenys nuolat sulaukia kalbančiojo pamokymų ir nurodymų, skatinančių aktyviau elgtis, apginti save ar aiškinančių, kokios gali būti nuolankumo pasekmès, plg.:

271) ĩmkis kûoki ọžsẹiemẹma / draibstâs ${ }^{90}$ ba_rẽkala / ẹ_vẹskas // 79

272) êk mệklệ / vọ_pavielộusi // 237

273) a_jau_apdrínkâa / ka_nàb_tẽp báskọbi? // 81

274) nabûk lộrbis / dộk i_marmũzẹ / ka_ẹ_kẹta sîni žẹnûotọ // 219

275) par_dẹ́dli sáva nulaidọ́ma pàtê ẹ_ràgùs dávẹ // 262

KTŽ kalbantysis kritiškai vertina nekasdienišką, išskirtiniu įprastinių darbų nebuvimu pasižymintị savo buvimą ne namuose: nedirbant praleistas ir apčiuopiamų naudingumo rezultatų nerodantis laikas vertinamas kaip pasyvi, betikslè veikla, į kurią buvo susigundyta įsitraukti. Toks vertinimas dažniausiai atskleidžiamas tam tikros struktūros sakiniais, kurių branduolį sudaro gana vaizdingu slinkties veiksmažodžiu su priešdèliu par- nusakomas tarinys su lokalizacijos laike ir (ar) erdvejje nuoroda, kartais greta pateikiant ir neịgyvendintą slampinèjimo tikslą ar tinkamos, bet praleistos veiklos apibūdinimą, plg.:

276) párk̂uokẹniejâu $u^{93}$ vẹ́sa dệina pọ_*pàlộnga // 162

277) vẹ́sa dệina párkramẹniejâu ${ }^{94}$ pọ_mĩesta // 183

278) párk̂omẹniejâu ${ }^{95}$ pọ́si dẹinũos / vọ_naradâu ni_vệina dũora grîba // 163

\footnotetext{
${ }_{88}$ pèrà - 'mušimas, lupimas' KTŽ 292

${ }^{89}$ užkãbavoti, oja, oje (hibr.) - 'užkabinti' KTŽ 137

${ }_{90}$ draibstýties, draíbstos, draîbstès - 'nerasti sau vietos; sėdinėti, gulinėti, klaidžioti ir pan.' KT 79

${ }^{91}$ mìklus, $\sim i-$ 'vikrus' KTŽ 237

92 apdrìnkti, $\sim$ sta, $\sim$ - 'pasidaryti neaktyviam, tingiam, aptingti' KTŽ 81

${ }^{93}$ kiokinéti, $\sim e ́ j a, \sim e ́ j \dot{j e}$ - 'pamažu vaikštinèti, kiūtinèti'; párkiokinèti - 'palengva vaikščioti kurị laiką' KTŽ 162

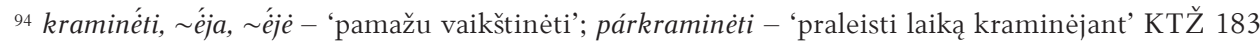

${ }^{95}$ párkiominèti - 'palengva pravaikštinèti kurị laiką’ KTŽ 163
} 
279) párkuorẹniejâu ${ }^{96}$ vẹ́sa dẹ̃ina / nọmệi bútûo kū_nûors nuvẽikẹs // 181

KTŽ kalbantysis pasyvumu laiko ir savo paties ar kito asmens veiklas, nepasižyminčias optimizmu ir spartumu, plg.:

280) ka_kẹtãsis e grêtâ dệrb / àlì natộr nužọgộma ${ }^{97} / / 263$

281) senâm žmũogộu nàbie nẽ nužongọ́ma /nẽ ọkátas ${ }^{98} / / 263$

\subsection{Adekvatūs tarpusavio santykiai}

Adekvatūs, lygiavertiški santykiai KTŽ kalbančiajam susiję su savojo ego, atkaklumo ir nepriklausomumo suvaržymu, plg.:

282) sọ̀_žmuogọ̀ givènộnt rẽk ẹ_nùlâidu // 262

283) àš ni_sọvệinọ žmúogọ̀ nanûorọ prệklitệiis 99 // 320

Todèl vertinant galimybes sutarti ir susitarti yra įprasta pabrèžti geranoriškumo būtinybę (žr. 212-214 sakinius), o beatodairiškai įrodinėjančiuosius savo tiesą mėgstama apibūdinti kaip nenuovokius ir nesukalbamus (žr. 215-217 sakinius), plg.:

284) jê nuories / e_sọgivêns // 131

285) sộ_pẹktọ̀ ${ }^{100}$ nieka nalaimîesi // 295

286) sọ̀gerọ vẹ̀sumèt gàli žmũogọ priprašitẹ // 104

287) jê nûori / rọoộukis kãp žmúogọs / vọ_nakàbẹniekis // 137

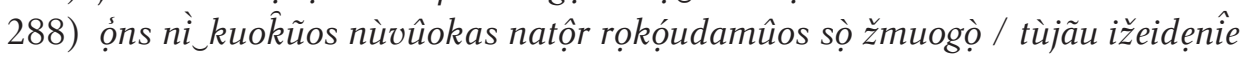
/ prišingàujẹs // 263

289) sọ̀_naravọ̣101 žmúogọ ni_pasẹrọoộusi dúorã / ni_sọsẹtãrsi // 251

KTŽ iliustracijose ryškiai reprezentuojama ir nuostata, kad bendravimo sèkmei vien tik geranoriškumo, kad ir abipusio, taip pat nepakanka, - natūralus noras bendrauti įmanomas tik esant asmenybių susiderinimui tarpusavyje ir bendravimo temų bei interesų mainams, plg.:

290) vèdộm sọ̣*marẹ nìkãp nalộb sọpộltệ102 kálbà / vọdàbãr sộ_verẹ dẹdlê sọ̀pộl // 325

${ }_{96}^{6}$ korinéti, $\sim \hat{e ́ j a}, \sim \overline{e ́ j e}$ - 'vaikštinèti lyg ko ieškant, valkiotis'; párkorinèti - 'praleisti laiką nieko neveikiant' KTŽ 181

97 nužangùmas - 'spartumas' KTŽ 263

${ }^{98}$ ukatà (sl.) - 'noras, ūpas' KTŽ 464

${ }^{99}$ prìklytis, ijas, ijès (sl.) - 'bartis, pyktis, kitiems trukdyti' KTŽ 320

100 piktas - 'piktumas, pyktis' KTŽ 295

101 narãvas, à (sl.) - 'užsispyręs, greit susierzinąs' KTŽ 251

102 supùlti, $\sim a$, supúola - 'sutapti, susiderinti' KTŽ 325 
291) ons i naẹlgus ${ }^{103}$ žmuogọs / sọ anọu nuores būtẹ i būtẹ // 124

Gerų santykių sẻkmę taip pat nulemia supratimas, kad kiekvienas turi būti atsakingas už save ir kad tarpininkavimas tam tikrose situacijose gali būti ir nelabai naudingas, pvz.:

292) ka_sọ̀_patẹ sọlígâtio4 / sọ̀_anọ̀ ẹ_ruokộukis // 215

KTŽ iliustracinė medžiaga rodo, jog žemaičiams geri tarpusavio santykiai yra pagristi galimybe lygiomis dalimis dalytis ne vien su malonumais susijusiais dalykais, bet ir užduotimis bei pareigomis. Tokį užduočių ir galimybių išsidalijimą fiksuoja ir žemaitiška leksika - lygiavertiškoms veiksmų atlikimo galimybėms ịvardyti žemaičiai pasitelkia ši aspektą išryškinančius prieveiksmius padaliuõ, paeĩliuo, padieniuõ, padienesiuõ, panakčiuõ, pakaitõms, pakaitaĩs ar neasmenuojamąsias veiksmažodžių formas ir pan., plg.:

293) saldâinu dávẹ vẹsệms pàdalộu $u^{105}$ // 267

294) napộlkẹt / vẹsẹ paẽilộu gâusẹt pọ_sáldâini // 268

295) rộpọtẹs mes_skộtâm pàdẹinesọôu // 268

296) pànaktộu mès sũodna sérgiejêm // 275

297) dẹrbsêm pàkaitũoms / núorêm bệngtẹ // 270

298) mès k̂ãule sérgiejiem pàkaitãs / ka_toriêejẹ paršộutệis // 270

299) tū_pũngọli nèšiem pasệkêisdamis // 325

Santykių adekvatumą taip pat nulemia ir duoto žodžio laikymasis, todèl KTŽ kalbantysis pabrèžia, kad pažadą reikia tesèti, nes meluojantis asmuo praranda pasitikejimą, plg.:

300) nagệldink vãkộu šệrdẹis / jê nágali / ta_ẹ_nažadiek // 107

301) tûokẹs vīiñonẹs tik šệrdi gệlda // 107

302) àš távẹs nábtẹkọ / tọ̀ vẹsumèt malộui // 227

303) àš sọ_maklũorês naprasệdedọ // 225

KTŽ kalbètojui lygiavertis bendravimas - pagrịstas dèmesingumu ir būtinybe kalbantis žiūrèti pašnekovui į akis, plg.:

304) rọkọ́udamûos veiziek tệisề iakis / vọ_nanairikisis ${ }^{106}$ i_šalis // 249

305) rọkọujẹtệis rẽk ì_akis veizietẹ / vọ_na_žvalgîtệis // 348

\footnotetext{
${ }_{103}$ ilgus, $\sim \bar{i}-\overline{\text { 'nuobodus, ilgesingas, liūdnas' } \overline{\mathrm{KT}} \mathrm{Z}} \overline{124}$

104 sulýgti - 'suderèti, sutarti' KTŽ 215

105 padaliuõ - 'iš eilès, visiems po lygiai, dalimis' KTŽ 267

106 nairýties, naĩros, naĩrès - 'sukinėtis, dairytis iš paniūrų, padilbų' KTŽ 249
} 


\subsection{Empatijos raiška}

KTŽ kalbančiojo empatiškumas ryškiausiai atsiskleidžia frazėse, apibūdinančiose vaikams (žr. 234-243 sakinius) ir seniems žmonèms (žr. 243-244 sakinius) skirtino dèmesio bei pagarbaus elgesio poreikị ir (ar) jo trūkumą, plg.:

306) kệik tọ̀ gàlì tū_vãka kalevûotẹ107 / kãp kûoki šọnni! // 141

307) díel_kũo tū_vãka tẽp kộnkẹnat? // 144

308) nakộlkûok ${ }^{108}$ têp tū_vāka / matâ / kûoks jáu ẹšbálẹs / sọsệrgs // 194

309) káp_anà e giedas natộr tẽp mūčitẹ tū_sáva vãka // 243

310) tū_vãka ànệi ội êội $i^{109} / / 463$

311) tệi vákã nabagútê kệnt prì_anũ // 248

312) kàs bộva par_klệkîms ${ }^{110}$ tū_vákũ / kãp gìvuolâtus klệkẹ ọžniekùs // 171

313) tas_vãks mizérẹjẹ vãrgst kâuras dẹinàs / vọ̀ ni_válgîitẹ kãp rẽkệnt nagâun // 241

314) jáu tûoki tuo_vãka plẹikẹ́ma par_namiera / ẹ_šẹrrẹ̣s skãud véizộnt // 306

315) vákã / načídīkẹties ẹš_séna žmúogãus // 64

316) tûoki čidẹjẹmûos / vọ_dàbâ ẹš_séna žmúogãus / nabovâu mátẹs // 64

KTŽ kalbantysis atjautimą asmeniui, su kuriuo neadekvačiai ar nepagarbiai elgiamasi, išryškina deminutyvinėmis apkalbamo asmens nuorodomis, agresyvų subjekto (ar subjektų) poveikį rodančiais predikatais, atviru savo emocinio vertinimo įvardijimu, plg.:

317) anâm nàbagộu vẹsûokẹs biedas ọnkrĩmt ${ }^{111}$ // 188

318) vẹsẹ̣ pộl ọt_vệršọ / vọ̣ọns žmuogélis namûok atsẹgín̂uote // 108

319) ont_*miegali vẹ̀sẹ kãp šọnnis pộl // 324

320) ta_mergệkẹ i túokì klaikšéle / mộn gãilọ ànũos // 167

321) ta_mergệkẹ tệkrà kloikšéle / gãilo ànũos mộn // 175

KTŽ kalbančiojo empatiniai gebėjimai išryškèja (o kartu tampa ir pavyzdžiu) demonstruojant pastabumą atviroms ar bandomoms nuslèpti artimųjų emocinèms reakcijoms, pvz.:

322) pàrẽt abọ́dọ tievọ kr̂̃úokdamọ // 21

323) kúo_tọ dúksâuji / a_skãud kàs?// 83

324) a_naženâ / kũo ànà kr̂̃úoke isẹkñãusọsi112 i_pũodẹška? // 178

\footnotetext{
${ }_{107}$ kaliavóti, $\sim$ ója, $\sim \overline{\text { óje }}$ (hibr.) - 'barti, persekioti, tyčiotis' KTŽ $\overline{141}$

108 kullkioti, ioja, ioje - 'nuolat barti, mušti' KTŽ 194

109 ùiti, ùja, ùjè - 'barti, persekioti' KTŽ 463

110 klìkymas - 'klikdymas, virkdymas' KTŽ 171

111 ankrìsti - 2. 'tekti, užgriūti (bẻdoms, nelaimèms)' KTŽ 188

112 issikniaũsti, $\sim a, \sim \dot{e}-2$. 'ịsikniaubti' KTŽ 177-178
} 
KTŽ kalbančiojo pasisakymuose ryškiai pabrèžiama, kad kiekviena gyva būtybė yra verta pagarbos ir neturi būti nei erzinama, nei kankinama, plg.:

325) nagệldink tâm šọnệi seẹrdệis / jē_dộudi / dộuk tū_kâula // 107

326) nàrẽk kọnkînte nìkuok̂̀u givuolélu // 144

327) namūčì / vẹsẹ̣ gìuuolātê nûor gīvêntẹ // 110

Pastebėjęs šios nuostatos pažeidimus KTŽ kalbantysis nukentejjusį padarą stengiasi įvardyti deminutyvais, o skriaudikams randa ịvairių negailestingumą išryškinančių apibūdinimų (pvz.: beširdis, bedušnikas, arkliaširdis ir pan.), plg.:

328) kam_sọtráiškê tū_kẹrmẹnệli / àš ni_veizîiete nágalọ // 451

329) tẹi_kemikàlâ í dáug nùstũoli pridáre paukštètêms // 155

330) ànệi tệkrẹ badũšninkâ / ka_ni_sáva vákũ nàgâilệs // 37

331) èsì bašệrdis / ka_gàlì várlẹs skrûostẹ // 41

332) a_ni_gãilesi nátọi / ka_tẽp mũcẹeji tū_ârkli // 97

333) tọ_esi_arklašệrdis ${ }^{113}$ / ka_têp galiejê darite // 30

Atjaučiančio elgesio būtinybès nuostatą KTŽ kalbètojas yra linkęs apibūdinti absoliučią gyvybès vertę pabrèžiančiais apibendrinimais, plg.:

334) kuožnâm vabalệ̣̂̂u brộngi gĩvasta // 109

335) jog_kũožnọ gî̀s dâkts nûor gīvêntẹ // 182

336) kũožnọs gî̀us pàdârs nûor gīvêntẹ // 267

337) dệâusis dàlĩks žmũogộu îr gívîba // 109

\section{IŠVADOS}

KTŽ iliustracinès medžiagos, atrinktos pagal etniškumu pagrịstų emociju dominantes, analizė parodè, kad visame KTŽ diskurse pastebima pozityvių emociju - stipraus ego, pasitikèjimo, atkaklumo - raiška ir ugdymas dažniau atsiskleidžia gynybinèse situacijose, o ne didžiuojantis savimi. KTŽ kalbančiojo pasisakymuose ryškiai matomos pastangos savo aplinkoje nuo mažens ir nuolat ugdyti atkaklų, atsakingą už savo veiksmus ir veiklą asmenį. Nepriklausomumas KTŽ kalbančiajam labiausiai susijęs su saugiu buvimu savo paties namuose. Savojo būsto sukūrimas vertinamas kaip nepriklausomumo ir saugumo garantas, todèl jam sukurti tam tikru gyvenimo momentu skiriamos visos pastangos, o būseną, patiriamą ịsikūrus, mègstama apibūdinti kaip susijusią su tikrumu ir pasitenkinimu įvardijant ją teigiamą rezultatą pabrèžiančia fraze - ir gyvenu. Pozityviai vertinamas emocijas atsveria kiek negatyvesni (ar negatyviai vertintini) emocinès raiškos aspektai - nerimas, jautrumas, intravertiškumas,

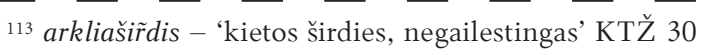


uždarumas, pasyvumas. Šių dviejų - pozityviosios ir negatyviosios emocinès raiškos - aspektų santykis lemia adekvačius kartu vienoje šeimoje ar bendruomenejje būnančiu asmenų tarpusavio santykius ir empatijos raišką. KTŽ iliustracinès medžiagos analizè, besiremianti prielaida, kad šis žodynas kaip plataus semantinio spektro kasdieniško kalbejimo iliustracijų visuma yra pajègus reprezentuoti KALBANČIOJO, perteikiančio daugybès nuasmenintų individų patirtis ir pasisakymus, galimybių paveikslą, leidžia iš nurodytųjų dominančių sudèliotuose žemaitiško emocinio lauko kontūruose pamatyti ypač ryškias pastangas kurti stabilius tarpusavio santykius. Kuriant tokius santykius stiprus ego gali ir turi prasiveržti iš uždarumo kiauto, o nerimo valdomi nepriklausomumas, intravertiškumas ir pasyvumas leidžia suvokti, kad jautrumas nesibaigia vien ties nuosavo skausmo suvokimo riba. Tai KTŽ kalbančiajam leidžia atkakliai siekti savo sumanymų iggvendinimo jaučiant kitą asmenị ir kuriant su juo adekvačius santykius, dalijantis džiugesį keliančiais pastebejimais ir stengiantis neịprastai atrodantị ar besielgianti artimą asmenį „,pažadinti“, perspèti ar apraminti. Taip pabrèžiamas emocinio stabilumo poreikis ir pačiam individui, ir su juo kartu gyvenantiems ar šalia esantiems asmenims. KTŽ gausu kalbančiojo frazių, kuriose trumpais paaiškinimais ar patarimais bandoma koreguoti kito asmens aktyvumo ar pasyvumo lygmenis. Tokie emocinio lauko parametrų kalboje tyrimo rezultatai paremia šiaurės žemaičių kretingiškių tarmės gyvybingumo (žr. Lubienė, Pakalniškienė 2014) idèją, nes svarbiausi žemaitiško emocinio išskirtinumo bruožai koreliuoja su etninei bendruomenei būtinomis išlikimo ypatybèmis.

Kalboje atsispindinčių žemaitiško emocinio lauko kontūrų aprašas yra tik viena dèlionès pagal Etninès priklausomybès determinuotų psichinių reiškinių tyrime išryškejjusių žemaičiams būdingu psichikos ypatybių suvestinę (Bliumas 1997) dalis. Kitos tyrime nurodytos žemaičių grupès tiriamiesiems būdingesnès intelektinès veiklos intensyvumo ir sèkmingumo bei sąveikos su daiktine ir socialine aplinka ypatybių realizacijos kai kuriais aspektais ypač ryškiai atsispindi KTŽ medžiagoje ir leidžia žemaičiams suvokti kai kurių savo pasisakymų ir elgesio modelių prasmę. Bet šių psichinès veiklos realizacijų kalboje aptarimas yra jau kitos publikacijos tema.

\section{ŠALTINIAI IR LITERATŪRA}

Aleksandravičius Juozas 2011: Kretingos tarmès žodynas, sud. Danguole Mikulènienè, Daiva Vaišnienè. Vilnius: Lietuvių kalbos institutas. 
Aliūkaitè Daiva, Mikulènienė Danguolè, Čepaitienè Agnè, Geržotaitè Laura 2017: Kalbos variantiškumas ir jo vertinimas perceptyviosios dialektologijos požiūriu: variantų ir vietų vaizdiniai. Vilnius: Vilniaus universiteto leidykla.

Babickienė Zofija 2005: Skolinių išlikimas tradicinėje šiaurès žemaičių kretingiškių tarmèje, - Baltistica. VI priedas, 7-16.

Bliumas Remigijus 1997: Aukštaičių ir žemaičių etnine priklausomybe determinuotų psichinių reiškinių savitumai. - Psichologija 17, 25-57. Prieiga internete: http: // www.zurnalai.vu.lt / psichologija / article / view / 9017 / 6762.

Coulson Seana 2001: Semantic leaps. Frame-Shifting and Conceptual Blending in Meaning Construction. Cambridge: Cambridge University Press.

Gage Nathaniel L., Berliner David C. 1994: Pedagogine psichologija. Vilnius: Alna litera.

Haspelmath Martin 2000: Indefinite Pronouns. Oxford: Oxford University Press.

Helm Bennet W. 2009: Self-love and the structure of personal values. - Emotions, Ethhics, and Authenticity. Consciousness and Emotion Book Series 6. Amsterdam / Philadelphia: John Benjamins Publishing Company, 11-32.

Judžentis Artūras 2012: Lietuviu kalbos gramatinès kategorijos. Vilnius: Vilniaus universiteto leidykla.

Lubienè Jūratè, Pakalniškienè Dalia 2014: Šiaurès žemaičių kretingiškių tarmès gyvybingumas: XXI amžiaus pradžios situacija. - Baltu filologiija 23(2), 75-86.

[Lüscher Max] The Lüscher Color Test 1971: Translated and edited by Ian A. Scott. Based on the Original German Text by Dr. Max Lüscher. New York, London, Toronto, Sydney, Tokyo, Singapore: Washington Square Press.

Mikulènienė Danguolè 2011: Juozo Aleksandravičiaus lituanistinè ir pedagoginė veikla. - Kretingos tarmés žodynas, aut. Juozas Aleksandravičius, sud. Danguolè Mikulènienė, Daiva Vaišnienè. Vilnius: Lietuvių kalbos institutas, VII-XII.

Myers G. David 2008: Psichologija. Vilnius: Poligrafija ir informatika.

Pajèdienè Jūratė 2018: Žemaitiškos tapatybès raiška: dẻlionè iš Kretingos tarmès žodyno (2011) pavyzdžių. - Acta Linguistica Lithuanica 79, 64-104.

Pakalniškienè Dalia, rec., 2018: Daiva Aliūkaitè, Danguolè Mikulènienè, Agnè Čepaitienè, Laura Geržotaite. Kalbos variantiškumas ir jo vertinimas perceptyviosios dialektologijos požiūriu: variantų ir vietų vaizdiniai. - Acta Linguistica Lithuanica 78, 259-263. 
Rorschach Hermann 1951 [1921]: Psychodiagnostics. A Diagnostic Test Based on Perception. Translation and Englisch edition by Paul Lemkau and Bernard Kronenberg. New York: Distributors for the U.S.A. GRUNE \& STRATTON INC. Prieiga internete: http://www.igorgrzetic.com/wp-content/uploads/2011/02/Herman-Rorschsch-Psychodiagnostics.pdf.

Rosinas Albertas 1996: Lietuvių bendrinès kalbos jevardžiai. Vilnius: Mokslo ir enciklopedijų leidykla.

Rutkovska Kristina 2017: Namai. Šeima. - Vertybès lietuvio pasaulevaizdyje, aut. Rutkovska Kristina, Smetona Marius, Smetonienė Irena. Vilnius: Akademinė leidyba, $87-148$.

Vaišnienè Daiva 2011: „Kretingos tarmès žodynas“: pagrindiniai medžiagos pateikimo principai. - Kretingos tarmès žodynas, aut. Juozas Aleksandravičius, sud. Danguolè Mikulènienė, Daiva Vaišnienè. Vilnius: Lietuvių kalbos institutas, XX-XXXVI.

Valeckienè Adelè 2006: İvardis. - Dabartinès lietuvių kalbos gramatika, red. Vytautas Ambrazas. Vilnius: Mokslo ir enciklopedijų leidybos institutas, 251-282.

Weigand Edda 2010: Dialogue - The Mixed Game. Amsterdam / Philadelphia: John Benjamins Publishing Company.

\section{Outline of the Samogitian Emotional Field as Reflected by Kretinga Dialect Dictionary (2011)}

\section{SUMMARY}

The present article is a continuity of the study on the expression of the emotional field of the speakers of the Northern Samogitian Dialect of Kretinga. The selection and analysis of the illustrative material from Kretinga Dialect Dictionary (hereinafter - KDD) by Juozas Aleksandravičius based on the dominants of ethnically determined emotions (cf. Bliumas 1997) revealed that the expression and development of positive emotions - strong ego, self-confidence and persistence - which are seen in the entirety of the discourse provided by the KDD more commonly manifest themselves in defensive situations rather than those when the speaker is proud of him/herself. The utterances of the KDD speaker clearly reveal the efforts made in one's environment to develop a persistent person responsible for his/her actions and activities continuously and from the early days. In the view of the KDD speaker, independence is mostly associated with safe existence in one's home. The creation of 
one's home is viewed as the guarantee of independence and security; hence, the maximum possible efforts can be made for that matter. Meanwhile, the state of mind which is experienced after the person has settled in his/her home is often described as that related with certainty and satisfaction by using the phrase highlighting the positive result - and I live. Positively evaluated emotions are counterbalanced by slightly more negative (or negatively evaluated) aspects of emotional expression - anxiety, sensitivity, introversion, reservedness, passiveness. The proportion between the two aspects - positive and negative emotional expression - determines adequate relationships of individuals co-existing in a single family or community and the expression of empathy. The analysis of the KDD illustrative material based on the assumption that, as an entirety of illustrations of daily speaking of a broad semantic spectrum, the dictionary in question is capable of representing the picture of the possibilities of the SPEAKER rendering the experiences and utterances of the multitude of depersonalized individuals, enables us to see very clear efforts of building stable interpersonal relationships within the outline of the Samogitian emotional field assembled out of the given dominants. When building such relationships, a strong ego may break through the shell of reservedness, whereas anxiety-driven independence, introversion and passiveness bring the understanding that sensitivity does not end with the boundary of perception of one's own pain. The above drives the KKD speaker to pursue his/her ambitions with persistence by feeling another person, establishing adequate relationships with him/her and by sharing joyful observations and/or questions and trying to "wake up", warn or calm down a close person who looks or behaves in an unusual way. This is how the need for emotional stability of the individual and the people who live or are next to him/her is highlighted. The KDD abounds in the speaker's phrases which attempt to correct the levels of activeness-passiveness of another individual by brief clarifications or pieces of advice. The discussed findings of the study dealing with the parameters of the emotional field as reflected in the spoken language support the idea of viability of the Northern Samogitian Dialect of Kretinga (see Lubiene, Pakalniškienè 2014), because the principal traits of the Samogitian emotional distinctiveness correlate with the peculiarities of survival which are vital for the ethnic community.

Itteikta $2019 \mathrm{~m}$. vasario $18 \mathrm{~d}$.

JŪRATÉ PAJE்DIENE்

Lietuviu kalbos institutas

Petro Vileišio g. 5, LT-10308 Vilnius, Lietuva

jurate.pajediene@lki.lt 